\title{
AN ANALYTICAL STUDY OF MONTHLY TURNOVER AND COST STRUCTURE OF RUBBER INDUSTRY IN KERALA
}

\begin{tabular}{|l|l}
\hline Dr. Adarsh & $\begin{array}{l}\text { Assistant Professor, Post Graduate Department of } \\
\text { Economics, S.N. College, Cherthala, Kerala, India. }\end{array}$
\end{tabular}

The present paper is an attempt to examine the monthly turnover and the cost structure of Rubber Industry in Kerala. The study of monthly turnover and the cost structure of Rubber Industry in Kerala are very important and much significant for the Rubber industry in Kerala. The researcher prepared a questionnaire keeping in mind all the important aspects related to indigenous rubber and import of rubber.

The present study is based on primary data. Primary data was collected from the Rubber industrial units (Sole Proprietor, Firm and Company) from three regions of Kerala i.e., Southern Region, Central Region and Northern Region through a structured questionnaire. Questionnaire was constructed after consulting the experts in the field of Rubber industry. Based on their suggestion, some items were deleted and some items were modified. The responses of the users were, by and large, encouraging. They responded freely in highlighting different aspects of rubber industry.

To conclude, there is significant difference in the monthly turnover for different Rubber Industrial Units in Kerala. In other words, we can say that as nature of ownership changes, there is a change in monthly turnover. Likewise, the percentage share of different components of cost namely overhead cost and fixed cost of Rubber Industry in Kerala based on ownership is different and it is found more for sole proprietorship and firm respectively. The percentage share of different components of cost of Rubber Industry in Kerala based on operation is same.

KEY WORDS: Monthly turnover, Cost structure, Rubber Industry, Overhead cost, Fixed cost.

JEL Codes:, D00, D24, L60, L65.

\section{INTRODUCTION}

There is a significant place for rubber industry in the economy of Kerala. The rubber industry of Kerala is one of its most important industries, accounting for the major amount of rubber production in the state. Rubber is the major agricultural product of Kerala and almost $90 \%$ of the total rubber production in India is accounted by the state of Kerala. The rubber industry in Kerala also provides employment to a large number of people of this region.
In this backdrop, the present paper is an attempt to examine the monthly turnover and the cost structure of Rubber Industry in Kerala. The study of monthly turnover and the cost structure of Rubber Industry in Kerala are very important and much significant for the Rubber industry in Kerala. The researcher prepared a questionnaire keeping in mind all the important aspects related to indigenous rubber and import of rubber. 


\section{METHODOLOGY}

The present study is based on primary data. Primary data was collected from the Rubber industrial units (Sole Proprietor, Firm and Company) from three regions of Kerala i.e., Southern Region, Central Region and Northern Region through a structured questionnaire. Questionnaire was constructed after consulting the experts in the field of Rubber industry. Based on their suggestion, some items were deleted and some items were modified. The responses of the users were, by and large, encouraging. They responded freely in highlighting different aspects of rubber industry.

Here, the sample comprises of two hundred and thirty three Rubber industrial units (233) of the total population (LM) of 590 with the Confidence level $=95 \%$, Confidence interval $=5 \%$, Level of Significance $=5 \%$ and the $Z$ value $=1.96$ (Two Tailed). The territorial spread of the field of investigation is confined to three major regions in the state i.e.: Southern Region (Thiruvananthapuram, Kollam, Pathanamthitta, Alappuzha), Central Region (Kottayam, Idukki, Ernakulum, Trissur, Palakkad, Malappuram), and Northern Region (Kozhikode,
Wayanad, Kannur, Kasaragod). From Southern Region, sixty three units $(27.0 \%)$ are selected and from Central Region one hundred and eighteen units $(50.6 \%)$ are selected and from Northern Region, fifty two units $(22.3 \%)$ are selected for the study. Since the exact target figure for Rubber manufacturing industrial units working in the state are available (590 units), systematic sampling method is used in the study.

\section{RESULTS AND DISCUSSION}

Now let us make an analysis of the monthly turnover and cost structure of Rubber industry in Kerala and test it with the following variables provided below.

\section{AREA OF STUDY, AREA OF OPERATION AND THE MONTHLY TURNOVER}

Here, we make an analysis on the Area of study and Area of operation of Rubber industry in Kerala with the monthly turnover.

Table: 1

Area of study, Area of operation and the monthly turnover

\begin{tabular}{|c|c|c|c|c|}
\hline \multicolumn{5}{|c|}{ Dependent Variable: Monthly turnover } \\
\hline Area & Area of Operation & Mean & Std. Deviation & $\mathbf{N}$ \\
\hline \multirow{4}{*}{ Southern Region } & Local & 1134203.24 & 1478936.33 & 32 \\
\hline & National & 2208110.02 & 1250182.01 & 17 \\
\hline & International & 2658445.47 & 1085934.62 & 14 \\
\hline & Total & 1762708.10 & 1477729.01 & 63 \\
\hline \multirow{4}{*}{ Central Region } & Local & 550074.00 & 801766.11 & 65 \\
\hline & National & 1170477.78 & 1128341.26 & 40 \\
\hline & International & 2141036.16 & 1121745.38 & 13 \\
\hline & Total & 935655.86 & 1080722.58 & 118 \\
\hline \multirow{4}{*}{ Northern Region } & Local & 1029098.94 & 1083289.52 & 29 \\
\hline & National & 1155078.98 & 1105307.90 & 17 \\
\hline & International & $\begin{array}{c}1917065.43333333 \\
360000\end{array}$ & $\begin{array}{c}1076183.42113822 \\
5400000\end{array}$ & 6 \\
\hline & Total & 1172742.40 & 1103686.96 & 52 \\
\hline \multirow{4}{*}{ Total } & Local & 808676.06 & 1098912.87 & 126 \\
\hline & National & 1405315.19 & 1218769.77 & 74 \\
\hline & International & 2319821.19 & 1107009.54 & 33 \\
\hline & Total & 1212191.44 & 1249762.26 & 233 \\
\hline
\end{tabular}

Source: Computed from field Survey

The average monthly turnover of southern region is $1762708.10 \pm 1477729.01$, central region
$935655.86 \pm 1080722.58$ and northern region $1172742.40 \pm 1103686.96$. 
Table: 2

Two- way ANOVA

Tests of Between-Subjects Effects- Monthly turnover

Dependent Variable: Monthly turnover

\begin{tabular}{|c|c|c|c|c|c|}
\hline \multicolumn{7}{|c|}{ Dependent Variable: Monthly turnover } \\
\hline Source & $\begin{array}{c}\text { Type III Sum of } \\
\text { Squares }\end{array}$ & df & Mean Square & F & Sig. \\
\hline Corrected Model & $90129303854236.120^{\mathrm{a}}$ & 8 & 11266162981779.516 & 9.270 & .000 \\
\hline Intercept & 361893264294336.800 & 1 & 361893264294336.800 & 297.775 & .000 \\
\hline Area & 17742730779576.547 & 2 & 8871365389788.273 & 7.300 & .001 \\
\hline Operation & 45286946612091.700 & 2 & 22643473306045.850 & 18.632 & .000 \\
\hline Area * Operation & 5910312612133.894 & 4 & 1477578153033.473 & 1.216 & .305 \\
\hline Error & 272232821513708.940 & 224 & 1215325096043.344 & & \\
\hline Total & 704734214487984.200 & 233 & & & \\
\hline Corrected Total & 362362125367945.100 & 232 & & & \\
\hline a. R Squared = .249 (Adjusted R Squared $=.222$ )
\end{tabular}

Source: Computed from field Survey

Univariate General linear model was examined and it found that statistically there is significant difference among the Rubber industry in Kerala based on its area $\mathrm{p}=0.001 ; \mathrm{p}<5 \%$. Similarly there is significant difference among the Rubber industry in Kerala based on its operation $p=0.000 ; p<5 \%$. The interaction effect is verified and found that there is no significant difference among the Rubber industry in Kerala based on its operation $\mathrm{p}=0.305 ; \mathrm{p}>5 \%$.

\section{NATURE OF OWNERSHIP AND THE MONTHLY TURNOVER}

Here, we make an analysis on the monthly turnover of Rubber industry in Kerala with the help of ANOVA Table provided below.

Table: 3

Nature of ownership and monthly turnover (Descriptive Statistics)

\begin{tabular}{|c|c|c|c|c|}
\hline & $\mathbf{N}$ & Mean & Std. Deviation & Std. Error \\
\hline Sole Proprietor & 121 & 832710.64 & 1048781.06 & 95343.73 \\
\hline Firm & 67 & 1330589.13 & 1330771.07 & 162579.56 \\
\hline Company & 45 & 2056292.16 & 1197152.34 & 178460.93 \\
\hline Total & 233 & 1212191.44 & 1249762.26 & 81874.64 \\
\hline
\end{tabular}

Source: Computed from field Survey

The average monthly turnover of Sole Firm 1330589.13 \pm 1330771.07 and Company Proprietorship form of business is $1212191.44 \pm 1249762.26$.

$832710.64 \pm 1048781.06$,

Table: 4

Nature of ownership and monthly turnover ANOVA

\begin{tabular}{|c|c|c|c|c|c|}
\hline \multicolumn{7}{|c|}{ ANOVA } \\
\hline & Sum of Squares & df & Mean Square & F & Sig. \\
\hline $\begin{array}{c}\text { Between } \\
\text { Groups }\end{array}$ & 50426665353594.310 & 2 & 25213332676797.156 & 18.591 & .000 \\
\hline $\begin{array}{c}\text { Within } \\
\text { Groups }\end{array}$ & 311935460014350.800 & 230 & 1356241130497.178 & Result \\
\hline Total & 362362125367945.100 & 232 & & Significant \\
\hline
\end{tabular}

Now it is imperative to examine the monthly turnover of Rubber Industry in Kerala with the Anova. Here Anova test was done for different Rubber Industrial Units in Kerala is 18.581 and the $\mathrm{P}$ Value obtained .000; $\mathrm{P}<0.05$. That is, there is significant difference in the monthly turnover for different Rubber Industrial Units in Kerala. In other words, we can say that as nature of ownership changes, there is a change in monthly turnover. 


\section{NATURE OF OWNERSHIP AND PERCENTAGE OF COSTS}

Here, we make an analysis on the different types of costs (Material Cost, Labour Cost, Machine Cost and Overhead cost) of Rubber industry in Kerala with the nature of ownership (Sole Proprietorship, Firm, Company) and Area of Operation (Local, National and International). Multivariate Analysis of Variance (MANOVA) was performed to examine the statistical significance. Thus one objective was formulated in this regard.
Objective:- To assess the effect on percentage of costs at Rubber industry in Kerala based on ownership and area of operation.

Hypothesis:- The effect on percentage of costs at Rubber industry in Kerala based on ownership and area of operation is identical.

Table: 5

Nature of ownership and costs (Descriptive Statistics)

\begin{tabular}{|c|c|c|c|c|c|}
\hline & ture on ownersn & & & & \\
\hline & Ownership & $\begin{array}{c}\text { Area of } \\
\text { Operation }\end{array}$ & Mean & Std. Deviation & $\mathbf{N}$ \\
\hline \multirow{16}{*}{ Material Cost } & \multirow{4}{*}{ Sole Proprietor } & Local & 46.156 & 5.8175 & 77 \\
\hline & & National & 46.375 & 6.1105 & 32 \\
\hline & & International & 45.333 & 4.2283 & 12 \\
\hline & & Total & 46.132 & 5.7270 & 121 \\
\hline & \multirow{4}{*}{ Firm } & Local & 45.077 & 5.2334 & 39 \\
\hline & & National & 46.000 & 5.4772 & 20 \\
\hline & & International & 46.000 & 5.5032 & 8 \\
\hline & & Total & 45.463 & 5.2752 & 67 \\
\hline & \multirow{4}{*}{ Company } & Local & 45.600 & 4.4522 & 10 \\
\hline & & National & 50.273 & 4.9683 & 22 \\
\hline & & International & 47.923 & 6.3438 & 13 \\
\hline & & Total & 48.556 & 5.5126 & 45 \\
\hline & \multirow{4}{*}{ Total } & Local & 45.778 & 5.5294 & 126 \\
\hline & & National & 47.432 & 5.8522 & 74 \\
\hline & & International & 46.515 & 5.4090 & 33 \\
\hline & & Total & 46.408 & 5.6425 & 233 \\
\hline & Ownership & $\begin{array}{c}\text { Area of } \\
\text { Operation }\end{array}$ & Mean & Std. Deviation & $\mathbf{N}$ \\
\hline \multirow{16}{*}{ Labour Cost } & \multirow{4}{*}{ Sole Proprietor } & Local & 17.753 & 5.1277 & 77 \\
\hline & & National & 16.969 & 4.6105 & 32 \\
\hline & & International & 17.667 & 4.5594 & 12 \\
\hline & & Total & 17.537 & 4.9160 & 121 \\
\hline & \multirow{4}{*}{ Firm } & Local & 17.795 & 4.7250 & 39 \\
\hline & & National & 18.150 & 4.8696 & 20 \\
\hline & & International & 15.125 & 4.5493 & 8 \\
\hline & & Total & 17.582 & 4.7678 & 67 \\
\hline & \multirow{4}{*}{ Company } & Local & 18.800 & 4.2635 & 10 \\
\hline & & National & 18.182 & 6.0130 & 22 \\
\hline & & International & 19.615 & 5.9797 & 13 \\
\hline & & Total & 18.733 & 5.5776 & 45 \\
\hline & \multirow{4}{*}{ Total } & Local & 17.849 & 4.9154 & 126 \\
\hline & & National & 17.649 & 5.0948 & 74 \\
\hline & & International & 17.818 & 5.3119 & 33 \\
\hline & & Total & 17.781 & 5.0085 & 233 \\
\hline \multirow{7}{*}{ Machine Cost } & \multirow{4}{*}{ Sole Proprietor } & Local & 12.390 & 2.4450 & 77 \\
\hline & & National & 12.625 & 1.7180 & 32 \\
\hline & & International & 11.917 & 1.8320 & 12 \\
\hline & & Total & 12.405 & 2.2120 & 121 \\
\hline & \multirow{3}{*}{ Firm } & Local & 12.462 & 1.5702 & 39 \\
\hline & & National & 13.000 & 1.6859 & 20 \\
\hline & & International & 13.000 & 1.6903 & 8 \\
\hline
\end{tabular}




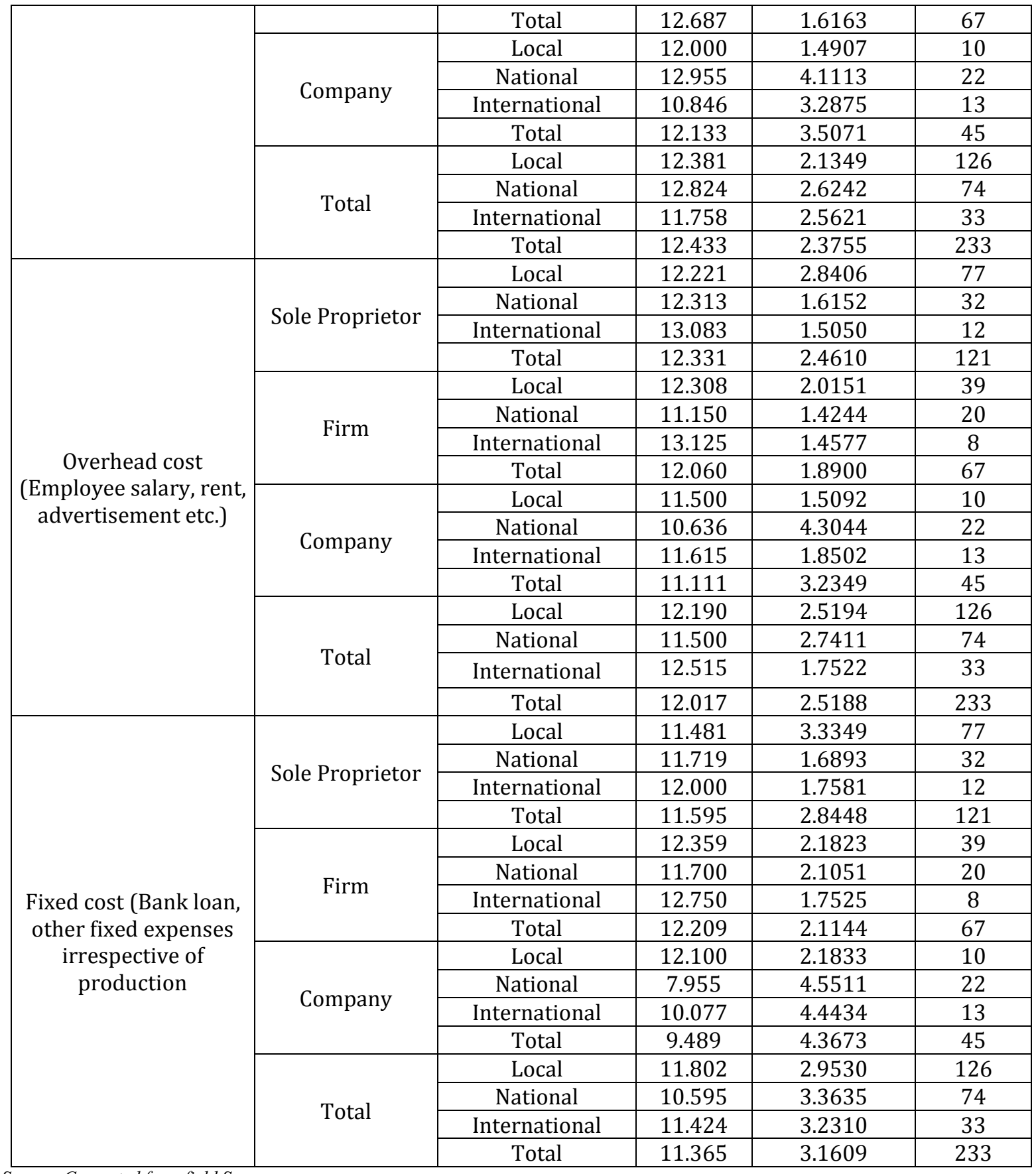

The percentage of labour cost incurred for

The percentage of material cost incurred for the Rubber Industry in Kerala was assessed. It found that the percentage of material cost of sole trader who specializes in local area is $46.15 \pm 5.81$, national level $46.375 \pm 6.11$ and at international level it is $45.33 \pm 4.22$

The percentage of material cost of firm which specializes in local area is $45.07 \pm 5.23$, national level $46 \pm 5.47$ and at international level it is $46 \pm 5.50$

The percentage of material cost of company which specializes in local area is $45.60 \pm 4.45$, national level $50.27 \pm 4.96$ and at international level it is $47.92 \pm 6.34$. ber Industry in Kerala was assessed. It found the Rubber Industry in Kerala was assessed. It found
that the percentage of labour cost of sole trader who specializes in local area is $17.75 \pm 5.12$, national level $16.96 \pm 4.61$ and at international level it is $17.66 \pm 4.55$.

The percentage of labour cost of firm which specializes in local area is $17.79 \pm 4.72$, national level $18.15 \pm 4.86$ and at international level it is $15.12 \pm 4.54$.

The percentage of labour cost of company which specializes in local area is $18.30 \pm 4.26$, national level $18.18 \pm 6.01$ and at international level it is $19.61 \pm 5.97$. 
The percentage of machine cost incurred for the Rubber Industry in Kerala was assessed. It found that the percentage of machine cost of sole trader who specializes in local area is $12.39 \pm 2.44$, national level $12.62 \pm 1.71$ and at international level it is $11.91 \pm 1.83$.

The percentage of machine cost of firm which specializes in local area is $12.46 \pm 1.57$, national level $13 \pm 1.68$ and at international level it is $13 \pm 1.69$.

The percentage of machine cost of company which specializes in local area is $12 \pm 41.49$, national level $12.95 \pm 4.11$ and at international level it is $10.84 \pm 3.28$.

The percentage of overhead cost incurred for the Rubber Industry in Kerala was assessed. It found that the percentage of overhead cost of sole trader who specializes in local area is $12.22 \pm 2.84$, national level $12.31 \pm 1.61$ and at international level it is $13.08 \pm 1.50$.

The percentage of overhead cost of firm which specializes in local area is $12.30 \pm 2.01$, national level $11.15 \pm 1.42$ and at international level it is $13.12 \pm 1.45$.

The percentage of overhead cost of company which specializes in local area is $11.50 \pm 1.50$, national level $10.63 \pm 4.30$ and at international level it is $11.61 \pm 1.85$.

The percentage of fixed cost incurred for the Rubber Industry in Kerala was assessed. It found that the percentage of fixed cost of sole trader who specializes in local area is $11.48 \pm 3.33$, national level $11.71 \pm 1.68$ and at international level it is $12 \pm 1.75$.

The percentage of fixed cost of firm which specializes in local area is $12.35 \pm 2.18$, national level $11.70 \pm 2.10$ and at international level it is $12.75 \pm 1.75$.

The percentage of fixed cost of company which specializes in local area is $12.10 \pm 2.18$, national level $7.95 \pm 4.55$ and at international level it is $10.07 \pm 4.44$.

Table: 6

Nature of ownership and costs- Two-way MANOVA

\begin{tabular}{|c|c|c|c|c|c|c|}
\hline \multicolumn{7}{|c|}{ Multivariate Tests ${ }^{\mathrm{a}}$} \\
\hline \multicolumn{2}{|c|}{$\underbrace{\overleftarrow{d}}_{\square=0}$} & $\frac{\mathscr{\varrho}}{\frac{\mathscr{J}}{\pi}}$ & E & 总总 & $\underset{\vdots}{\grave{0}}$ & is \\
\hline \multirow{4}{*}{ Intercept } & Pillai's Trace & 1.000 & $71344921.460^{\mathrm{b}}$ & 5.000 & 220.000 & .000 \\
\hline & Wilks' Lambda & .000 & $71344921.458^{\mathrm{b}}$ & 5.000 & 220.000 & .000 \\
\hline & Hotelling's Trace & 1621475.488 & $71344921.458^{\mathrm{b}}$ & 5.000 & 220.000 & .000 \\
\hline & Roy's Largest Root & 1621475.488 & $71344921.458^{b}$ & 5.000 & 220.000 & .000 \\
\hline \multirow{4}{*}{ Ownership } & Pillai's Trace & .090 & 2.095 & 10.000 & 442.000 & .024 \\
\hline & Wilks' Lambda & .910 & $2.112^{b}$ & 10.000 & 440.000 & .022 \\
\hline & Hotelling's Trace & .097 & 2.129 & 10.000 & 438.000 & .021 \\
\hline & Roy's Largest Root & .084 & $3.725^{\mathrm{c}}$ & 5.000 & 221.000 & .003 \\
\hline \multirow{4}{*}{ Operation } & Pillai's Trace & .101 & 2.341 & 10.000 & 442.000 & .011 \\
\hline & Wilks' Lambda & .901 & $2.344^{\mathrm{b}}$ & 10.000 & 440.000 & .011 \\
\hline & Hotelling's Trace & .107 & 2.347 & 10.000 & 438.000 & .010 \\
\hline & Roy's Largest Root & .079 & $3.510^{c}$ & 5.000 & 221.000 & .005 \\
\hline \multirow{4}{*}{$\begin{array}{l}\text { Ownership } \\
\text { Operation }\end{array}$} & Pillai's Trace & .128 & 1.476 & 20.000 & 892.000 & .081 \\
\hline & Wilks' Lambda & .876 & 1.481 & 20.000 & 730.607 & .080 \\
\hline & Hotelling's Trace & .136 & 1.483 & 20.000 & 874.000 & .079 \\
\hline & Roy's Largest Root & .080 & $3.553^{c}$ & 5.000 & 223.000 & .004 \\
\hline \multicolumn{7}{|c|}{ a. Design: Intercept + Ownership + Operation + Ownership * Operation } \\
\hline \multicolumn{7}{|l|}{ b. Exact statistic } \\
\hline
\end{tabular}

Source: Computed from field Survey

The result in the MANOVA table shows that Wilks' Lambda value based on ownership is 2.112; $\mathrm{P}=.022, \mathrm{P}<0.05$; statistically significant. Thus Null hypothesis is rejected. That means the percentage share of different components of cost of Rubber Industry in Kerala based on ownership is different. Similarly Wilks' Lambda value based on operation is 2.344; $\mathrm{P}=.011, \mathrm{P}<0.05$; statistically significant. Thus Null hypothesis is rejected. That means the percentage share of different components of cost of Rubber Industry in Kerala based on operation is different. The interaction effect of the Wilks' Lambda value is $1.481 ; \mathrm{P}=.080, \mathrm{P}>0.05$; statistically not significant. Thus Null hypothesis is 
accepted. That means the percentage share of different components of cost of Rubber Industry in
Kerala based on operation is same.

Table: 7

Nature of ownership and costs -Tests of Between-Subjects Effects

\begin{tabular}{|c|c|c|c|c|c|c|}
\hline Source & $\begin{array}{c}\text { Dependent } \\
\text { Variable }\end{array}$ & $\begin{array}{l}\text { Type III Sum } \\
\text { of Squares }\end{array}$ & df & Mean Square & $\mathbf{F}$ & Sig. \\
\hline \multirow{5}{*}{ Corrected Model } & Material Cost & $457.514^{a}$ & 8 & 57.189 & 1.849 & 0.069 \\
\hline & Labour Cost & $138.156^{b}$ & 8 & 17.27 & 0.681 & 0.708 \\
\hline & Machine Cost & $54.151^{\mathrm{c}}$ & 8 & 6.769 & 1.208 & 0.295 \\
\hline & Overhead cost & $94.492^{\mathrm{d}}$ & 8 & 11.812 & 1.921 & 0.058 \\
\hline & Fixed cost & $348.850^{\mathrm{e}}$ & 8 & 43.606 & 4.96 & $0.000^{*}$ \\
\hline \multirow{5}{*}{ Intercept } & Material Cost & 318460 & 1 & 318460.044 & 10295.511 & $0.000^{*}$ \\
\hline & Labour Cost & 46528.1 & 1 & 46528.063 & 1834.367 & $0.000^{*}$ \\
\hline & Machine Cost & 22455.9 & 1 & 22455.948 & 4007.858 & $0.000 *$ \\
\hline & Overhead cost & 21165.4 & 1 & 21165.388 & 3441.929 & $0.000^{*}$ \\
\hline & Fixed cost & 18947.9 & 1 & 18947.928 & 2155.425 & $0.000^{*}$ \\
\hline \multirow{5}{*}{ Ownership } & Material Cost & 131.424 & 2 & 65.712 & 2.124 & 0.122 \\
\hline & Labour Cost & 79.506 & 2 & 39.753 & 1.567 & 0.211 \\
\hline & Machine Cost & 17.046 & 2 & 8.523 & 1.521 & 0.221 \\
\hline & Overhead cost & 43.183 & 2 & 21.592 & 3.511 & $0.032^{*}$ \\
\hline & Fixed cost & 115.816 & 2 & 57.908 & 6.587 & $0.002^{*}$ \\
\hline \multirow{5}{*}{ Operation } & Material Cost & 128.514 & 2 & 64.257 & 2.077 & 0.128 \\
\hline & Labour Cost & 9.663 & 2 & 4.831 & 0.19 & 0.827 \\
\hline & Machine Cost & 22.542 & 2 & 11.271 & 2.012 & 0.136 \\
\hline & Overhead cost & 36.394 & 2 & 18.197 & 2.959 & 0.054 \\
\hline & Fixed cost & 83.193 & 2 & 41.597 & 4.732 & $0.01^{*}$ \\
\hline \multirow{5}{*}{$\begin{array}{l}\text { Ownership * } \\
\text { Operation }\end{array}$} & Material Cost & 115.977 & 4 & 28.994 & 0.937 & 0.443 \\
\hline & Labour Cost & 74.884 & 4 & 18.721 & 0.738 & 0.567 \\
\hline & Machine Cost & 19.156 & 4 & 4.789 & 0.855 & 0.492 \\
\hline & Overhead cost & 16.139 & 4 & 4.035 & 0.656 & 0.623 \\
\hline & Fixed cost & 101.527 & 4 & 25.382 & 2.887 & 0.023 \\
\hline \multirow{5}{*}{ Error } & Material Cost & 6928.75 & 224 & 30.932 & & \\
\hline & Labour Cost & 5681.68 & 224 & 25.365 & & \\
\hline & Machine Cost & 1255.07 & 224 & 5.603 & & \\
\hline & Overhead cost & 1377.44 & 224 & 6.149 & & \\
\hline & Fixed cost & 1969.14 & 224 & 8.791 & & \\
\hline \multirow{5}{*}{ Total } & Material Cost & 509193 & 233 & & & \\
\hline & Labour Cost & 79487 & 233 & & & \\
\hline & Machine Cost & 37329 & 233 & & & \\
\hline & Overhead cost & 35120 & 233 & & & \\
\hline & Fixed cost & 32412 & 233 & & & \\
\hline \multirow{5}{*}{ Corrected Total } & Material Cost & 7386.27 & 232 & & & \\
\hline & Labour Cost & 5819.84 & 232 & & & \\
\hline & Machine Cost & 1309.22 & 232 & & & \\
\hline & Overhead cost & 1471.93 & 232 & & & \\
\hline & Fixed cost & 2317.99 & 232 & & & \\
\hline \multicolumn{7}{|c|}{ a. R Squared $=.062$ (Adjusted R Squared $=.028$ ) } \\
\hline \multicolumn{7}{|c|}{ b. R Squared $=.024$ (Adjusted R Squared $=-.011)$} \\
\hline \multicolumn{7}{|c|}{ c. R Squared $=.041$ (Adjusted R Squared $=.007$ ) } \\
\hline \multicolumn{7}{|c|}{ d. R Squared $=.064$ (Adjusted R Squared $=.031$ ) } \\
\hline \multicolumn{7}{|c|}{ e. R Squared $=.150$ (Adjusted R Squared $=.120$ ) } \\
\hline
\end{tabular}


From the Anova table it is clear that statistically there is no significant difference among the percentage of different components of cost based on the ownership of Rubber Based Industries in Kerala, except Overhead $\operatorname{cost}(\mathrm{p}=0.032)$ and Fixed cost $(p=0.002)$. Similarly statistically there is no significant difference among the percentage of different components of cost based on the operation of Rubber Based Industries in Kerala, except Fixed cost $(p=0.001)$. The interaction effect shows that statistically there is no significant difference among the percentage of different components of cost of Rubber Based Industries in Kerala, except Fixed cost $(\mathrm{p}=0.023)$.

\section{CONCLUSIONS}

The important conclusions of the present analysis are the following.

- The average monthly turnover of Rubber based Industries in Kerala in southern region is Rs. 1762708, central region Rs.935655 and for northern region, the turnover is Rs. 808676 .

- The average monthly turnover of Local Rubber based Industries in Kerala is Rs.656153 National Rs. 1405315 and for International, the turnover is Rs. 2319821.

- The average monthly turnover of Sole Proprietorship type Rubber based Industries in Kerala is Rs. 832710 Firm Rs. 1330589 and for Company, the turnover is Rs. 2056292.

- The material cost incurred for the Rubber Industry in Kerala was assessed and it found that $46.40 \% \pm 5.64$, labour cost $17.78 \% \pm 5.00$, Machine Cost $12.43 \% \pm 2.37$, Overhead cost (Employee salary, rent, advertisement etc.) $12.017 \% \pm 2.51$, Fixed cost (Bank loan, other fixed expenses irrespective of production) $11.365 \% \pm 3.16$.

To be more specific, the percentage share of different components of cost namely overhead cost and fixed cost of Rubber Industry in Kerala based on ownership is different and it is found more for sole proprietorship and firm respectively. The percentage share of different components of cost of Rubber Industry in Kerala based on operation is same.

\section{REFERENCES}

1. Bhattacharya S.N, (1980) Rural Industrialization in India, B R Publishing Corporation, Delhi.

2. Chadha G.K. and P.P. Sahu (2003) Small Scale Agro-industry in India: Low Productivity is Its Achilles Heel; Indian Journal of Agricultural Economics; Vol. 58.

3. Economic Review, (2018) Kerala State Planning Board, Pattom, Thiruvananthapuram.

4. FAO, (1997) The State of Food and Agriculture, Agro-Processing Industry and Economic
Development, FAO Agriculture Series No. 30, Rome.

5. Fare, Rolf, Goss Kopf, Shawna and Kokkelenberge, Edward, (1989). Measuring Plant Utilization and Technical Change: A NonParametric Approach, International Economic review, Vol.30, No.3.

George J. Mouly (1963) The Science of Educational Research, American Book Company.

6. Hull, J. Christopher and Ijem, Bemey, (1987), "Helping Small Firms grow, an Implementation approach". Australia: Croomhelm.

7. Ooman, M.A., (1967). Small scale Industries in Kerala-A case Study of the Role of Small Industries in Economic Growth, Kerala University, Thiruvananthapuram. 